\title{
A Comparative Study of State Social Policies on Education and Its Shadow in South Korea and Iran
}

\author{
Abbas Madandar Arani ${ }^{1}$, Young Chun Kim² \& Mohammad Jafari Malek ${ }^{3}$ \\ ${ }^{1}$ Lorestan University, Lorestan, Iran \\ ${ }^{2}$ Chinju National University of Education, Chinju, South Korea \\ ${ }^{3}$ Islamic Azad University (Zanjan Branch), Zanjan, Iran \\ Correspondence: Abbas Madandar Arani, Lorestan University, Lorestan, Iran. E-mail: arani.a@lu.ac.ir
}

Received: July 11, 2016

Accepted: August 5, 2016

Online Published: December 26, 2016

doi:10.5539/res.v9n1p80

URL: http://dx.doi.org/10.5539/res.v9n1p80

\begin{abstract}
Education and private tutoring activities particularly are under influence of state social policies. The paper uses term "social policy" to show macro social and political attitudes of each state toward education. This paper compares social policies concerning education and its shadow in six states of South Korea with their four counterparts in Iran from 1980 to 2010. An overview of each state's policy in both countries provides two main similarities. First, during the last three decades, policies did not control the rapid expansion of the shadow education system. Second, the state policies indicated a contradictory situation which simultaneously limited and accelerated the expansion of private tutoring activities. Despite these similarities, state policies necessarily did not lead to the same results. While, change and transformation in the political structure in South Korea (i.e., from a totalitarian toward a neoliberal system) presumably has redefined the role of the shadow education system as a tool in the service of social and economic development of the country; In Iran, however, the political system, through a cyclical policy process (i.e., closed to semi-open to closed), seems to have accelerated a "brain drain" phenomenon as the outcome of private tutoring activities.
\end{abstract}

Keywords: educational policies, private tutoring, shadow education, social policies, South Korea, Iran

\section{Introduction}

In this study, we want to examine and compare state social policies on education and its shadow in South Korea and Iran. Stevenson and Baker (1992, p. 2) defined shadow education as a "set of educational activities outside formal schooling that are designed to improve a student's chances of successfully moving through the allocation process". In fact, role of education in human life over the past century led to the expansion of private tutoring activities in all corners of the globe. This expansion is not same in all societies and it seems that there are Metropol and a periphery area of shadow education growth. For example, while South Korea (hereafter Korea), Taiwan, Hong Kong, Singapore, and Japan can be seen as a main territory of phenomenon; in another part of the globe-like Iran-this process is slow, but with growing trend. Despite the differences between countries in terms of nature, size and growth of private supplementary tutoring, there is a common government interest in the phenomenon. In all countries, politicians and policy makers are concerned about private tutoring activities and its different functions. One reason is that shadow education has great impact on state social policy. Therefore, different states have tried to examine different policies on private tutoring and its development. It seems that these policies are on a continuum from a complete prohibition to a full release. The paper tries to examine state policies on shadow education in Korea and Iran through two objectives: first determines social and educational policies; and second, indicates that same policies necessarily have not led to the same results. Time period of comparison is from 1980 to 2010 in both Korea and Iran. 


\section{Approach}

Our approach in this paper is historical and comparative. In fact, social policies and educational practices strongly depend on history and the development of the societies in which they are embedded. To capture this, we follow a historical approach in presenting social and educational policies. Although the paper format does not allow a more detailed on historical and political transformation in both societies, our main source of data is existing research contributions and national and international reports about Korea and Iran. We first briefly reviewed existing discussions on the concepts of social and educational policies, then explaining the different forms of state policies on education and private tutoring activities in the two national contexts. Of course, we are aware that the political terms may not have the same meaning in different national contexts and that this can complicate my interpretation, but this can be an advantage rather than a deficit for a deeper understanding of state policies on education and its shadow. This is the basis for comparative discussion. In comparative studies, making "strangers familiar" and "familiar stranger" is a well known method among researchers. Therefore comparing is not necessarily limited to neighboring countries or societies with similarities. In many cases, it may be the most different systems have same consequences or systems with the slightest difference have different implications (Manzon, 2014, p. 98). In relation to present paper also initially seems that there is less similarity between Korea and Iran. What immediately comes to mind is the common presence of both countries in a very vast geographical range of Asia continent, while their ethnic, linguistic, religious, political, and social differences are clearly obvious. Nevertheless, the application of making "strangers familiar" indicates that two countries with minimum degree of similarity could have the same experience in many social policies. In fact, it shows that to what extent state social policies in education can be similar. It also reveals that to what extent social policies or educational practices can lead to a country's development or undesirable economic and social outcomes.

\section{Social and Educational Policies}

In this section two questions should be answered: What are social and education policies; and what are different types of state policies on shadow education. To answer the first question, different definitions of social policy have been presented by scholars of social science, but a common feature of them is an essential role of the state to determine it. Skocpol and Amenta (1986, p. 132) pointed out that if social policies are defined in the broadest possible terms as "state activities affecting the social status and life changes of groups, families, and individuals", then states have always had social policies. Cheyne, O'Brien and Belgrave $(2005$, p. 3) believe that "social policy might be described as actions that affect the well-being of members of a society through shaping the distribution of and access to goods and resources in that society" or "social policy is the study of the state in relation to the welfare of its citizens" (Alcock, Daly, \& Griggs, 2008; as quoted in Qarakhani, 2014, p. 72). However, a common feature of social policies is its generality among all states regardless of their political structures. In fact, as state regards itself as the prime actor in the domain of social welfare, therefore "social policy development has occurred in both authoritarian and democratic regimes" (Bangura \& UNRISD, 2007; as quoted in Qarakhani, 2014, p. 72). This prepares a suitable ground for scholars to compare state policies on different aspects of social affairs regardless of political differences. From this point of view, it is possible to find similarities among state social policies in two different countries like South Korea and Iran.

From an education perspective, the present paper considering definition of Walsh, Stephens and Moore (2000, p. 7) on social policy as "the plans, strategies and approaches that governments adopt when deciding what to do about issues and problems that affect social welfare", focuses on specific aspects of social policy, e.g., education (and especially shadow education). In fact, education has been particularly significant as an instrument of social policy, in the sense not only of policies for welfare, but also as policies intended to deal with the structure of society (Spicker, 2015). Some scholars distinguish between social policy and education policy, whereas education policy addresses the equality of opportunities, but social policy addresses equality of outcomes (Beblavý, Thum, \& Veselkova, 2013). In reality, there is no distinguishing difference between these two. In the education arena, both social policy and education policy come in the form of legislation, regulations and laws that the Parliament, the State and the Ministry of Education has approved and have decided to implement it. Ratification and implementation of the legislation largely depends to three main characteristics of state capacities, autonomy and centralization (Amenta \& Carruthers, 1988; as quoted in Qarakhani, 2014, p. 74). However, these features are heavily influenced by the overall economic outlook and political orientation of the state. In this paper, based on the current political division of Korea and Iran, we have divided state in Korea to three categories of totalitarian, developmental and neoliberal and in Iran into four groups of traditional leftist, modern rightist, modern leftist and the principalist. According to these categories, now we can examine state policies on education. 
With regards to the second question "what is state policies on shadow education" and despite the development of private tutoring activities, still there is less research on how the politicians look at this economic sector and how their policies affect it. In a report prepared for the European Commission, Bray (2011) reveals that even in developed countries for a long time, many policy makers were preferred to ignore the private tutoring activities. $\mathrm{He}$ indicated that some EU Member States have major gaps in their regulations, others have ambiguous regulations and yet others have clear regulations that are not rigorously implemented (p. 8). However, it seems that many politician and policy makers start to have more concern about this phenomenon. For example, in the beginning years of 2000s, Bray (2003) reported that many governments in countries of socialist bloc in Eastern Europe and central Asia ignored the expansion of private tutoring activities. After 6 years, Silova (2009) found that out of 12 countries of region, six countries have developed legal frameworks for regulating private tutoring market. Lao (2014) in Thailand found that while the state has given much attention to commercial regulations for safety and customers' protection, there is little attention on education aspects such as curriculum, quality assessment and qualification of tutors. New evidence comes from Turkey. Aydagül (2014) informed that the recent Turkish state declared a strong political willingness and a policy proposal that will either close private tutoring centers down or convert them to private schools. The state proposal caused a major public debate on the positive and negative aspects of private tutoring, particularly in terms of its effects on educational outcomes, equality of opportunity in society, and on who benefits from it and how much.

However, at the first step it is important to conceptually clarify what aspect of the private policy is being discussed. Ball (1994; as quoted by Lao, 2014, p. 477) pointed out that "it is not difficult to find the term 'policy' being used to describe very different things at different points in the same study". On the one side, Bray (1999) differentiated the government response private tutoring activities based on the governmental overall "approach" and categorize it to five main approaches, i.e., Laissez-faire approach, monitoring but not intervention, regulation and control, encouragement and mixed approach and prohibition. On the other side, Kim (2013; quoted by Lao, 2014, p. 478) maps out the types of governmental responses on private tutoring. There are policies on mainstream public education, which intended to influence private tutoring. These policies included the forms of the assessment systems, revision and improvement of national education curriculum and higher educational entrance examination. These can be further differentiated into educational policies such as pedagogy, class size, curriculum, teacher qualifications and commercial policies such as transparency, financial arrangement and management (Bray \& Lykins, 2012). Finally, Lee, C., Lee, H. and Jang (2010) divided government policy responses to private tutoring to three macro, meso, or micro levels. This paper, based on the Lee, Lee and Jang's typology tries to examine macro state policies on shadow education in Korea and Iran.

\subsection{State Social Policies in Korea and Iran}

From a political dimension after World War II, Korea comes out the dominance of the Japanese occupation while was divided into two parts. Although during this war, Iran also was divided into two parts by Russia in the North and Britain in South, but with more luck and as a bridge of victory, found her unity. In the early 1950s, while Korea was one of the poorest countries in the world; in Iran, Mohammed Mossadegh as Prime Minister decided to nationalize the oil industry to give more prosperous economy. The attempt failed through a coup against his government (Risen, 2000). By the beginning of 1960s until the end of 1970s, General Park in Korea and Shah in Iran ruled their countries. Both tried to pave the way for the country's economic and social development through a totalitarian and pro-West regime. Despite the differences between the two leaders, many similarities can be found between them too. With the great support from West and as a political partner in the region, both leaders were the initiator of many social and economical policies and plans in their underdeveloped country. However, their authoritarian rule saw numerous human rights abuses (see Billet, 1990; Rasler, 1996). Opinion is thus split regarding their legacy between those who credit General Park and Shah for their reforms and those who condemn them authoritarian way of ruling their countries. Older generations who spent their adulthood during these two dictators' rule tend to credit Park and Shah for building the economic foundation of the country. Finally, after two decades of sovereignty, a sad fate has happened for both in the 1979. Shah, who wanted - in his own words - to forward Iranian to "gates of the great civilization" (Najmabadi, 1987) was confronted with a national revolution, lost his kingdom and died in Cairo alone, while at the same time General Park was assassinated. After the death of Shah and Park, two nations did not follow the same path over the next three decades. Iranians were led by an Islamic regime, while the Koreans, has taken great strides towards democracy. Before starting main section of the paper, let briefly have a glance at the present situation of both countries through statistic mirror from 1980 to 2010.

From economic position, Korea's Human Development Index (HDI value) for 2012 is 0.909 - in the very high human development category - positioning the country at 12 out of 187 countries and territories. Between 1980 
and 2012, Korea's HDI value increased from 0.64 to 0.909 , an average annual increase of about 1.1 percent. In addition, between these three decades Korea's life expectancy at birth increased by 14.6 years, mean years of schooling increased by 4.3 years and expected years of schooling increased by 5.6 years. Korea's GNI per capita increased by about 417 percent between 1980 and 2012 (Korea: Human Development Report, 2013). Iran covers 1,873,959 square km, is located in the Middle East with access to the Caspian Sea from the north and the Persian Gulf from the south. Iran's population, according to the last census is 75,149,669 people (Statistical Center of Iran, 2012). Iran's Human Development Index (HDI value) for the year 2012 was 0.742 . This puts the country in the "high human development" category. Iran's current position is 76 out of 187 countries. More than this, Iran has made considerable progress in human development when measured over the past 30 years. According to UNDP calculations, between the years 1980 and 2012, Iran's HDI value increased by 67 percent—or at an average annual increase of about 1.6 percent. During the same period, for other countries in the High Human Development group (the group containing Iran), the average annual gain was only about half of what Iran managed -0.73 percent. For all countries on the planet, the average gain was even less - only 0.69 percent. This means that Iran's annual growth in its HDI was over double the global average. Simultaneously, this would imply that - from a human development standpoint—during the period 1980-2012, Iran's policy interventions were both significant and appropriate to produce improvements in human development. The Report also says that Iran achieved the second highest reduction in HDI shortfall—among developing countries - during the 22 year period between 1990 and 2012. Only one country (Korea) was able to do better (Iran: Human Development Report, 2013). Despite advances in subjects like human development index, control of population rate, literacy and expansion of higher education among women, yet in many other indicators Iran has not a good condition. The following table indicates the superiority of Korea on Iran in various areas.

Table 1. South Korea \& Iran's social, economic and educational indicators (number or percentage)

\begin{tabular}{cccc}
\hline Indicators & Year & South Korea & Iran \\
\hline Population growth rate (average annual \%) & $2010-2015$ & 0.5 & 1.3 \\
Urban population (\%) & 2013 & 83.8 & 69.4 \\
Population aged 0-14 years (\%) & 2013 & 14.9 & 23.8 \\
Life expectancy at birth (females and males, years) & $2010-2015$ & $84.6 / 77.9$ & $74.6 / 72.1$ \\
Gross domestic product (million current US\$) & 2012 & $1,129,598$ & 551,588 \\
Income per capita (current US\$) & 2013 & 23,180 & 10,695 \\
Unemployment (\% of labour force) & 2010 & 3.2 & 12.2 \\
Adult literacy rate & 2012 & 98 & 85 \\
Education: Government expenditure (\% of GDP) & $2006-2012$ & 5.1 & 3.7 \\
Education: Primary-secondary gross enrollment ratio (f/m per 100) & $2006-2012$ & $99.1 / 100.4$ & $92.1 / 96.0$ \\
Higher education student rate (f/m per 100) & 2014 & $39 / 61$ & $64 / 36$ \\
Human development index & 2013 & 0.891 & 0.749 \\
\hline
\end{tabular}

Source: UNdata, 2015 \& UNDP Report, 2013.

From political dimension, the politics of Iran take place in a framework of presidential democracy and theocracy guided by an Islamist ideology. Iran has an elected president, parliament (or Majlis), and an "Assembly of Experts" (which elects the Supreme Leader), and local councils. In practice, in Iran, the president acts same as prime minister. For this reason, the real political power is in the hands of the leader of the revolution (Menashri, 2001). Nevertheless, the president is elected through a general election and he is responsible for preparation and implementation of social and economic policies. The presidential term is a four-year in which a person can run for two successive periods. Over the past three decades (1980-2010), in Iran, four people acted as a head of the executive branch. Despite the relative stability of power in Iran, the Korea has witnessed the presence of 8 presidents in power. Considering the aim of paper on thestate's policies in education - and shadow education-in both countries, comparison is done between the presidents who were in power at the same time. Thus, for the period of 1980-1988, I will compare Chun Doo-hwan policies with Mousavi management, for the period of 1988-1996, Roh Tae-woo and Kim Young-sam policies with Rafsanjani management, for the years of 
1996-2004, Kim Dae-jung with Khatami's policy, and for the period of 2004-2012, Roh Moo-hyun and Lee Myung-bakpoliciesare compared with Ahmadinejad management.

\subsection{South Korea Experience}

Although the government's response to the growth of the shadow education in South Korea backs to 1960s and Park Chung Hee's government, but in this paper I examine the policies of states from 1980s onwards.

1) Jeon, Doo-Hwan (1980-1988): General Chun Doo Hwan came to power in 1980 through a military coup. One of educational reform initiated by Hwan was ban of certain kinds of shadow education. This policy was proposed during his campaign as a political promise to gain public support, as shadow education was considered a serious social problem (Kim \& Lee, 2010). He selected this educational problem to address as one of his first measures of social reform. Chun's government announced the 7.30 Education Reforms, which was a drastic measure in the history of educational policymaking in Korea. Park (2010, p. 586) found that these drastic measures met mixed responses from the population. The lower classes were generally in favor of these measures while the middle and high classes were unhappy about the draconian state control on educational opportunities and ban on private tutoring. In fact, these families often violated the ban, taking the risk of being punished by the regime, in order to provide private tutoring to their children discreetly. As Lee, Lee and Jang (2010) pointed out, although Hwan's policy on shadow education failed to obtain the intended outcomes of removing this system and private tutoring activities continued secretly, but its policy goals and provisions were, to a large extent, reflected in subsequent anti-shadow education measures until 2000 (p. 101).

2) Roh Tae-woo and Kim Young-sam (1988-1998): During the presidency of these two presidents, main educational reform confronting shadow education was in the college examination for reducing household expenditure on private tutoring classes. Lee, Lee and Jang (2010, p. 101) believe that government negative perspectives on private tutoring led to improving the quality of public education. It was a step forward, as Roh Tae-woo and Kim Young-sam's governments came to realize that an expansion of shadow education is due to lack of quality in the main school system (Kim \& Chang, 2010). To improve education system, both presidents' policies reflected in efforts such as reducing student-teacher ratio, assessing teacher performance, and introducing differential curricula.

3) Kim Dae-jung (1998-2003): Dae Jung Kim government tried to link education policy to "marketism" based on "productivity". His government changed the name of the department of education from the Ministry Of Education (MOE) to the Ministry of Education \& Human Resources Development (ME \& HRD), and the status of the president of that department was enhanced to that of Deputy Prime Minister on 2001 (Kim, 2004). Kim like two former presidents of Korea has urged educational policy makers to reduce educational burdens and costs on students and parents, caused by the examination-oriented school curriculum and the severe competition for university entrance examinations. As a rapid solution to relieve private tutoring burdens on both educational consumers and providers, Kim government suggested abolishing examinations in schooling. Regardless of these efforts, it seems that under Kim's government and for the first time, shadow education system found legal legitimacy, because the Korean Constitutional Court declared the law prohibiting private tutoring activities unconstitutional.

4) Roh Moo-hyun and Lee Myung-bak (2004-2012): As Lee, Lee and Jang (2010) have pointed out the Roh administration's policy responses to shadow education heavily emphasized the role of the public education system in the reduction of shadow education (p. 102). Efforts made to accomplish this goal included building an e-learning system; offering differential and supplemental classes and providing after-school programs. In addition, expansion of the Foreign Language High Schools in particular was suppressed during the Roh regime (Song, 2003). In 2009, the Myung-bak Lee government attempted, once again, to reduce the demands for shadow education by improving the quality of the public education system through efforts like grant greater autonomy to individual schools with regards to teacher recruitment and curriculum operation; launch the 300 Project for the Diversified High School System; establish the teacher assessment system and administer the national level student achievement evaluation (Lee, C., Lee, H., \& Jang, 2010, p. 103). However, the Lee government's focus was on the defects of the formal education system rather than the system of shadow education. In addition, The Lee administration's announcement of the educational deregulation measures was considered a historic decision for the country's educational policymaking, as it was the first-ever hands-off approach to school operations by the central government. Many of the deregulation measures 
of Lee's conservative government are likely to pave the way for the emergence of a more explicit school hierarchy, promoting competition and the growing private education market while dismantling the country's decades long egalitarian approach to educational policymaking.

\subsection{Iran Experience}

a. Mir Hosain Mosavi (1980 to 1988): Under leadership of Ayatollah Khomaiyni, Mir Hosain Mosavi was prime minister of the revolutionary government. By the beginning of his administration, the Iran-Iraq war began with a period of 8 years. In terms of political groups in Iran, Mousavi was belonged to the traditional leftist. The traditional leftist was a combination of individuals and groups demanding social equality, nationalization of economic and religious reform. From economic dimension, he pioneered a bond-based economy, which many believe was responsible for a fair distribution of goods among the people throughout the Iran-Iraq war (Rai, 2014). Since during the past half-century, Iran's economy is heavily dependent on oil revenues, he spent US\$217 billion (about $60 \%$ ) of oil revenues on premium costs war (Fathollahi, 2012). Mosavi state saw education as the main instrument for re-socializing people to Islamic values. Education was viewed as a major tool in reaching this ideal (see Kaviani, 2006; Paivandi, 2013). The first fundamental educational reform introduced by the revolutionary government was transformation of the curriculum, through revision of textbooks, especially those in social studies, humanities, and religion, a task that was completed within two years (Mehran, 1997). In line with this policy, all private schools shutting down and their activities were banned. The Supreme Council of Cultural Revolution was established in 1980. By the end of the Cultural Revolution of 1980-1983, 40,000 teachers were expelled or compulsorily retired (Hoominfar, 2014). However, Mosavi's government was heavily involved in the war and did not prioritize education. As Non-government schools were closed and quality of education reduced, demand for private tutoring-especially among the middle and high class families-increased drastically. In addition, because of shortage of higher education institutes, there was a tough competition among students, which again led to increasing demand for shadow education. In practice, Mousavi's state policies to close non-government schools had backfired result and increases the demand for the shadow system. However, to reduce the demand for entry to university, Mousavi's state had implemented an educational plan entitled "work and knowledge". In this scheme, high school students one had to go day per week for an internship in one of the industrial centers (Ministry of Education, 1999). The scheme was abolished in the next government without practical effect on the national university entrance examination. Increase the number of employees of the Ministry of Education, and closing schools nationwide in many cities because of the war were other features of the Mousavi's state.

b. Rafsanjani (1988-1996): After the end of war in 1988, Rafsanjani state who called himself "pragmatist", took power. He argued in the light of economic development, there is a possibility of independence and justice (Qarakhani, 2014). Rafsanjani first Five-Year Plan aimed to reduce state control in the economy, marketize the distribution of consumer goods, borrow capital on international financial markets, and reform the country's multi-tiered currency exchange rates (Harris, 2013; Rai, 2014). During two terms presidency, Rafsanjani state spent US $\$ 174 / 5$ billion of oil revenues (Fathollahi, 2012). From education dimension, during Rafsanjani' management and for the first time, education performance was publicly criticized by politicians. The authorities blamed the shortcomings of the existing system on excessive centralization and too little attention to regional or local needs; inflexibility with regard to the differing needs and interests of students, especially the sharp separation of academic and technical-vocational programs; concentration on preparation for higher education, at the expense of immediate entry into the work force; emphasis on memorization and rote learning, rather than analytical thinking; and high percentages of students repeating grades, causing waste of resources. In this situation, Rafsanjani state did three basic steps: 1) Implementation of a new upper secondary education system; 2) Establishing new schools entitled "governmental unique schools"; and 3) Encourage people to invest in education and establishing of private schools through granting land, loan and administrative support. The major differences introduced by the reforms are reduction in secondary schooling from four to three years and introduction of the credit system to eliminate repeating grades. Once having received the secondary-school diploma, students who wish to enter a university take an additional one-year course geared to the highly competitive university entrance examination (Ministry of Education, 1999). Governmental unique schools would accept students through the entrance exam and teachers and classes were better equipped. These schools had permission to taking a portion of cost of education from parents. A more controversial change in the state policies in educational has been the 
establishment of "nonprofit" private schools. Despite an increase in public education expenditure from 3.89 percent of gross national product to 5.75 percent in 1993, rapid increases in the school-age population and growing demand for education led to legislation permitting private individuals and non-governmental organizations to invest in education at all levels, provided that they offer the same curricula as in public schools. This move has provoked heated debate among educators and policy makers alike. Rafsanjani period is a re-started time of flourishing of the shadow education system in Iran (Asriran News Agency, 2009). Establishment of new universities and higher education centers has prepared a huge market for private lessons. The government would also encourage people to establish private tutoring centers. For the first time, state's desire was aligned with the needs of parents.

c. Khatami (1997 to 2004): Mohammad Khatami attracted global attention during his first election to the presidency when he captured almost $70 \%$ of the vote. Khatami had run on a platform of liberalization and reform. During his two terms as president, Khatami advocated freedom of expression, tolerance and civil society, constructive diplomatic relations with other states including those in the Asia and European Union, and an economic policy that supported a free market and foreign investment. The 2004 World Bank report on Iran concludes that "after 24 years marked by internal post-revolutionary strife, international isolation, and deep economic volatility, Iran is slowly emerging from a long period of uncertainty and instability" (Siddiqi, 2005). The removal of oil revenues to the state prior to the Khatami government was US\$189/5 billion (Fathollahi, 2012). In the field of education, at the beginning Khatami has selected a conservative as Minister of Education. The most important action of Khatami's first minister was closing of governmental unique schools. The ministry believes that these schools spreading social inequality. In the second term of presidency, Khatami chose a reformist as a minister of education. The most important activities of the new minister was increasing of teacher salary, formation of students' school boards, selection and appointment of school principals by teachers, cash vouchers and mortgage for teachers and permission for school buildings and facilities lease for arts and sports activities by the private sector. Although Mehran (2010) believes that Khatami could not make any fundamental reform in Iran's educational system, but his belief in individual freedom caused more tolerance about shadow education. Therefore, Khatami's time could be the beginning of a golden period for those who were interested in investing in private tutoring activities. Official statistics show that during the second period of his presidency, the number of private tutoring centers increased from 2,200 in 2000 to over 4,600 in 2004 (Ministry of Education, 2014).

d. Ahmadinejad 2005 to 2012: Mahmoud Ahmadinejad was the main political leader of the Alliance of Builders of Islamic Iran, a coalition of conservative political groups in the country. During his presidency, Ahmadinejad was viewed as a controversial figure within Iran, as well as internationally. He has been criticized domestically and internationally for his economic policies and alleged disregard for human rights (see Hafezi, 2008; Memarian, 2010). In Ahmadinejad state use of oil revenues in the economy rose to its maximum. During 7 years (2005-2011), more than 542 billion dollars of oil revenue was spent in the economy. Compare with the previous states of Iran, Ahmadinejad's state had largest oil revenues over the past 100 years, but despite this huge financial resource, his state recorded in decrease in economic growth, unemployment and inflation rates (Rai, 2014). At the end of his government, the actual rate of inflation had risen to over 45\% (Fathollahi, 2012). In the education sector, Ahmadinejad-unlike previous presidents-during 8 years has appointed three ministers for Education (Asriran News Agency, 2009). The Ahmadinejad state policy on shadow education can be described in three distinct steps: 1) University admission base on student's residence priority; 2) Legislation to remove national university entrance examination; 3) Establish of new school entitled "Board of Trustees schools". At the time of Rafsanjani and Khatami, the owners of private tutoring centers were permitted to conduct classes for male and female students in a same building at different days; but Ahmadinejad government strongly opposed to it and announced that the building should be just for girls or boys and students of the opposite sex are not allowed to use the same building. This policy made the situation very difficult for the owners. Nevertheless, during Ahmadinejad regime and for the first time after 2 decades, universities found more than 200,000 vacant capacities, especially in the field of humanities. A situation that continues today. Therefore, from last years of Ahmadinejad presidency, private tutoring centers were faced two problems: First, sharp decline in the number of customers, and second, increase of competition among centers for conducting classes with emphasis on quality or unreal propaganda. 


\subsection{Comparing States Policies}

Like any other comparison, here also there are similarities and differences between the two countries. In the beginning and regardless of the state's management, three points should be noted. First, the shadow education system in both countries has been rising over the past two decades, although, expansion and generalization of this system in Korea is larger than Iran. Second, the government's strong involvement in education is one of the common features in both countries. Third, as already mention it, I am following Lee, Lee and Jang (2010) macro pattern of policy responses to private tutoring which are equalization of schools, prohibition of private tutoring, enhancement of public education, and the provision of supplementary tutoring programs to increase access. Since the paper focuses only on 1980 onward, only last three types of policies are considered.

* Prohibition of Private Tutoring: In the 1980s and at the two extreme sides of Asia, the military government of JeonDoo Hwan and Islamic revolutionary government of Mir Hosain Mosavi have selected same policy on shadow education that was ban of private tutoring activities because it was considered a serious social problem (Choi, 2012; Mesri, 2008). In Korea, with this new set of restrictions, only college students and registered hakwon (for profit education centers) lecturers could provide shadow education, whereas in Iran it was totally banned on any forms and for any providers. In both governments shadow education (and in Iran, especially for school teachers) was viewed as educational corruption which undermined social trust (Seth, 2005; Mesri, 2008). As Park (2010) has reported despite this ban, in Korea many affluent parents found ways to provide illegal shadow education services, and the fees for those illegal services significantly increased considering the high risk for the tutors, but in Iran and at the beginning years, many of Iranian families have seen this policy as a long step towards equality in educational opportunities (Akrami, 2013). However, the ban not only failed to meet its goal, but the educational corruption backfired. However, war's cost pressure and a sharp drop in the quality of education was provided a ground for prevalence of private classes. Therefore, the ban was canceled in 1988. It is interesting to note that the ban was continued in Korea till end of 1990s.

* Enhancement of Public Education: During the 1990s, in both Korea and Iran social concerns were expressed in regard to the increasing growth of the shadow education system. In Korea the growth of shadow education was mainly at the primary and lower secondary levels, while in Iran it was at upper secondary level thought to be directly related to the high-stakes exams for entering universities (Lee, Lee, \& Jang, 2010; Yar Mohammadian, Sohrabi, \& Arizi, 2003). In Korea and in 1995, the Roh Tae-woo government proposed the 5.31 Educational Reform Plans to enhance quality of the public education system and offer after-school programs. In 1997, Kim Young-sam management introduced Educational Plans for alleviating overheated Private Tutoring and Reducing Household Spending on Shadow Education. In contrast, in Iran president Rafsanjani policy was to encourage people to establish private schools and tutoring centers. At the same time he tried to establish new schools and universities across the country, which it also increases the demand for shadow education. In fact, one of the fundamental differences between Korea and Iran during this decade was that in Korea the government's policies were recognition and control of the shadow education system, whereas in Iran Rafsanjani policy was recognizing and encouragement of it.

* Enhancement of Public Education: From political aspect, there are many similarities between Kim Dae-jung and Mohammad Khatami (1998-2003). Both of them believed in democracy, individual liberty and social reform. While Kim was awarded the Nobel Prize, Khatami advocated the dialogue among civilizations. From educational dimension, the Kim government tried to link education policy to "marketism" based on "productivity". The benchmark of the political shift was when the nation's Constitutional Court declared in 1990 that the restrictions on private lessons were unlawful as they violated the personal freedom and right to education (Jo, 2013). This declaration demonstrated a political and social shift in the perception of shadow education from being viewed as a social ill to a legitimate social norm. Khatami also believed participation of parents, teachers and local administrators in education, but his plans were accompanied by fierce opposition from conservatives (Mehran, 2010). However, Khatami policy on shadow education was more implicit support of the establishment of private tutoring centers and explicit distinct on people participation at educational fees and costs of their children. In reality, it can be said that compared to the previous states in Iran, individual freedom, parents right to select schools and teacher assessment were increased in the time of Khatami.

* Provision of Supplementary Tutoring Programs: While Roh Moo-hyun and Lee Myung-Bak governments (2004-2012) represent that Korea moves faster towards economic and social development, 
Ahmadinejad regime can be seen as a retrogression in Iran's development process (Ghadar \& Sobhani, 2011). Despite these political and social differences, many similarities can be found between educational policies of these people in education and especially its shadow. In 2004, Roh Moo-Hyun administration proposed the Educational Plans for the Reduction of Shadow Education Cost through the Normalization of Public Education. This plan differs from the previous governmental measures to shadow education due to its explicit attempts to provide a variety of forms of supplementary tutoring programs within the mainstream schooling system (Lee, C., Lee, H., \& Jang, 2010, p. 102). In 2009, Lee Myung-Bak government again proposed the Educational Policies for the Reduction of Shadow Education through the Enhancement of the Competitativeness of Public Education, weighing students' high school records and utilizing admission officers, rather than relying on the test scores. In Iran and during the presidency of Ahmadinejad, university capacity has increased drastically. In addition, the Ministry of Education has permitted opening of private tutoring centers more quickly and easily. The aim was to increase competition among centers to reduce the cost of tuition. At the same time, he permitted school administrators to conduct private classes in after school hours for students and collecting money from parents. In this way, schools attracted more students and tried to hire famous center tutors. The sum of these policies in recent years has resulted in extremely low numbers of customers for private tutoring centers, which has led to more bankrupt for investors.

Table 2. A comparison between state policies on shadow education in South Korea and Iran from 1980 to 2010

\begin{tabular}{|c|c|c|}
\hline Presidents/policies & South Korea & Iran \\
\hline \multirow{3}{*}{$\begin{array}{c}\text { JeonDoo Hwan \& Mir } \\
\text { HosainMosavi }\end{array}$} & - Ban on shadow education & - Ban on shadow education \\
\hline & - 7.30 Educational Reform Measure & - Work and knowledge scheme \\
\hline & - 5.31 Educational Reform Plans & - Emphasis on egalitarianism through \\
\hline \multirow[t]{3}{*}{$\begin{array}{l}\text { Roh Tae-woo and Kim Young-sam } \\
\text { \& Akber Hashmi Rafsanjani }\end{array}$} & $\begin{array}{l}\text { Educational Plans for alleviating } \\
\text { overheated Private Tutoring and }\end{array}$ & $\begin{array}{l}\text { establishment of schools and } \\
\text { universities }\end{array}$ \\
\hline & $\begin{array}{l}\text { Reducing Household Spending on } \\
\text { Shadow Education }\end{array}$ & $\begin{array}{l}\text { - Recognizing and encouraging of } \\
\text { shadow education }\end{array}$ \\
\hline & - Emphasis on privatization of education & - Emphasis on teacher assessment \\
\hline \multirow[t]{3}{*}{$\begin{array}{c}\text { Kim Dae-jung \& Mohammad } \\
\text { Khatami }\end{array}$} & - Legal legitimacy of shadow education & $\begin{array}{l}\text { - Emphasis on people participation in } \\
\text { education }\end{array}$ \\
\hline & & $\begin{array}{l}\text { Facilities lease for arts and sports } \\
\text { activities by the private sector }\end{array}$ \\
\hline & - Increasing school autonomy & - University admission base on student \\
\hline \multirow{2}{*}{$\begin{array}{l}\text { Roh Moo-hyun and Lee } \\
\text { Myung-bak \& Mahmood } \\
\text { Ahmadinejad }\end{array}$} & $\begin{array}{l}\text { Educational Plans for the Reduction of } \\
\text { Shadow Education Cost through the } \\
\text { Normalization of Public Education }\end{array}$ & $\begin{array}{l}\text { residence } \\
\text { - Legislation to remove national } \\
\text { university entrance examination }\end{array}$ \\
\hline & $\begin{array}{l}\text { - Educational Policies for the Reduction } \\
\text { of Shadow Education through the } \\
\text { Enhancement of the Competitativeness } \\
\text { of Public Education }\end{array}$ & $\begin{array}{l}\text { Permission for school conducting } \\
\text { private tutoring classes }\end{array}$ \\
\hline
\end{tabular}

\section{Conclusion}

Same as other social phenomena, shadow education may have positive and negative effects in different social contexts. The main goal of the present paper was to shed a light on response of different presidential managements in South Korea and Iran on shadow education system. According to what was said in the previous parts of paper, I would like to come to a few basic points as a conclusion:

The first point is that in both countries and in the 1980s, governments were very strict and idealistic about this matter. The Korean military government and the revolutionary government of Iran took the decision to shut down private classes. It seems that in both societies and at the beginning, prohibition of private tutoring activities was welcomed by the people, but later in South Korea, the middle class disagreed with this decision; while the country's economic problems and lack of quality of education made Iranian families to ignore government's policy. During the 1990s, the government of the state authority-oriented has changed with development-oriented government in both countries. The development-oriented government aims usually are to increase the equality of educational opportunities that promote growth through the development of primary and secondary education. 
The quantitative growth of schools and universities can be considered as a common government policy in both countries which automatically increased private tutoring activities. During the 2000 s, governments in both countries, for various reasons wanted more involvement of the private sector in education. The main emphasis of the government is improvement of the education system and monitoring of its shadow. It seems that now the government in both countries has reached to this stage, although the policy on education quality and supervision of shadow education are not similar.

The second point is that in reality shadow education responds to social demand for better education. That's why the confronting of a human need is not simply possible. On the one hand, all people are demanding equality in educational opportunity. On the other hand, many parents want their children to be best in educational competition. Conflicts between human desires are not limited to the realm of schooling, but it is more sensible in education. This complex situation with regard to the amount of pressure exerted by various interest groups led governments to examine and adopt different policies on shadow education. People think this is responsibility of government to prepare educational equality for all. Conscience reminds everyone that access of only some children to better education is one of the great inequalities. But, when some people are seeking inequality, many parents think they should participate in the competition too. The result is "education fever". South Korea's experience shows that in recent decades, governments caught between conflicting of parents' demands (Byun, 2010; Lee, 2001; Park, 2010). Increase in the number of schools and universities, and removing very tough universities' examination to somewhat can destroy unequal educational opportunities. This will also reduce the economic pressure on household income. But the experience of both countries-Korea in 1997, when the government tried to stop national exam and unsuccessful experience of Iran in complete elimination of university entrance examination-reveals that this policy is not simple and easy. In 2007, the social pressure on the Korean government raises a new issue called "right of choice" (Park, 2010). Because of parents' pressure, the government was forced to return to the national exam. In both countries, this situation makes a conflict between government social and educational policies. In Korea, this contributed to a tension between the egalitarian idea that the entire school system should be "uniform in content and standard" and the more elitist tendency to assign every school and school district a place in a hierarchy of status (Byun, 2010). Thus the tension between egalitarianism and elitism in the South Korean education system makes two results: First, it leads to excessive investment in higher education; and second facilitates the expansion of shadow education. In Iran, the situation is also very complicated. For example, from one side Ahmadinejad government always emphasized on social justice and equality, and on the other side prepared a suitable ground for different varieties of private tutoring (even in governmental schools) which increased more pressure on the poor people.

The last point to be noted is about consequence of shadow education in the country's development process. Over the past three decades, governments in both countries have attempted to provide educational opportunities for all. In South Korea, governments "egalitarian policy from one side and role of the shadow education system through elitism policy from other side led country from a poor society to a developed one". In this sense, role of shadow education might be appreciated. In Iran, all governments since the Islamic Revolution in 1979 have followed the policy of educational equality. The egalitarian policy increased literacy rate from $48 \%$ in 1979 to $95 \%$ at present. Social demand for higher education has caused to establish many universities. Country's student population on average is 5500 per 100,000 located Iran at the top of the Islamic countries. Nevertheless, the development of higher education does not necessarily lead to social and economic development in Iran. Nearly 150 thousand of the best young Iranians leave the country every year. This shows that in reality, the development of education alone will not achieve development for the country. According to Iran's National Elites Foundation, a government-run organization that supports academically gifted and high-achieving students, during the past two years, at least 40 percent of top-performing students with undergraduate degrees in science and engineering left the country to pursue advanced degrees. From 2009-2013, net emigration from Iran was 300,000 (Motevalli, 2014). In fact, the policy of equality of educational opportunity increased peoples' interest in higher education. That's why parents try to send children to private classes to increase chance of university admission. As a result, during the past decade private tutoring centers have increased over 5 times. In fact, despite heavy investment of government and parents in education (and its shadow) the result for the country is a high rate of unemployment among university graduates and brain drain. Foreign policy, nuclear program and the lack of real democracy in Iran, made education an unproductive investment (Lutz, Cuaresma, \& Abbasi-Shavazi, 2010). This is a fundamental difference between Iran and South Korea. In this situation, is it possible to evaluate role of shadow education as a negative and a tool for accelerating brain drain. This is an important question facing policy makers and educational planners that deserves an answer for it. 


\section{References}

Akrami, S. K. (2013). I was against Non-Governmental Schools: An Interview with Former Minister of

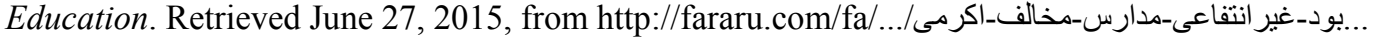

Asriran News Agency. (2009). Ten Ministers for Education. Retrieved June 27, 2015, from http://www.asriran.com/fa/news/77609/10

Aydagül, B. (2014). Closing Down Prep Schools Another Poor Education Policy Decision. Today Zaman. Retrieved June 20, 2015, from http://www.todayszaman.com/anasayfa_closing-down-prep-schools-another-poor-education-policy-decisio n_345641.html

Beblavý, M., Thum, A., \& Veselkova, M. (2013). Education and Social Protection Policies in OECD Countries: Social Stratification and Policy Intervention. Journal of European Social Policy, 23(5), 487-503. https://dx.doi.org/10.1177/0958928713499174

Billet, B. L. (1990). South Korea at the Crossroads: An Evolving Democracy or Authoritarianism Revisited. Asian Survey, 30(3), 300-311. https://dx.doi.org/10.2307/2644567

Bray, M. (1999). The Shadow Education System: Private Tutoring and Its Implications for Planners. Paris: UNESCO International Institute for Educational Planning.

Bray, M. (2003). Adverse Effects of Supplementary Private Tutoring: Dimensions, Implications, and Government Responses. Series. In Ethics and Corruption in Education. Paris: UNESCO International Institute for Educational Planning. Retrieved July 2, 2015, from http://unesdoc.unesco.org/images/0013/001330/133039e.pdf

Bray, M. (2011). The Challenge of Shadow Education: Private Tutoring and Its Implications for Policy Makers in the European Union. Brussels: European Commission. Retrieved July 2, 2015, from http://www.nesse.fr/nesse/activities/.../the-challenge-of-shadow-education-1

Bray, M., \& Lykins, C. (2012). Shadow Education: Private Supplementary Tutoring and Its Implications for Policy Makers in Asia. Manila: Asian Development Bank.

Byun, S. (2010). Does Policy Matter in Shadow Education Spending? Revisiting the Effects of the High School Equalization Policy in South Korea. Asia Pacific Education Review, 11, 83-96. https://dx.doi.org/10.1007/s12564-009-9061-9

Cheyne, C. O., Brien, M., \& Belgrave, M. (2005). Social Policy in Aotearoa New Zealand: A Critical Introduction. UK: Oxford University Press.

Choi, J. (2012). Private Tutoring and Educational Inequality: Evidence from a Dynamic Model of Academic Achievement in Korea. University of Pennsylvania. Retrieved July 2, 2015, from paa2013.princeton.edu/papers/130384

Fathollahi, J. (2012). A Review of Economic Performance of Four Governments. Fasa News Agency. Retrieved July 12, 2015, from http://sarvefasa.com/khabar/139

Ghadar, F., \& Sobhani, R. (2011). It's the Economy, Stupid: Trials and Tribulations of the Iranian Economy. Harvard International Review, 33(1), 22-26.

Hafezi, P. (2008). Influential Iran Cleric Slams Ahmadinejad on Economy. Reuters. Retrieved September 21, 2015, from http://www.reuters.com/article/2008/08/13/us-iran-economy-cleric-idUSHAF34205520080813

Harris, K. (2013). The Rise of the Subcontractor State: Politics of Pseudo-Privatization in the Islamic Republic of Iran. International Journal of Middle East Studies, 45(1), 45-70. https://dx.doi.org/10.1017/S0020743812001250

Hoominfar, E. (2014). Challenges of Monolingual Education (MA Thesis). Ohio: Graduate College of Bowling Green State University. Retrieved September 21, 2015, from https://etd.ohiolink.edu/!etd.send_file?accession=bgsu1404055112\&disposition=inline

Iran Human Development Report. (2013). Iran (Islamic Republic). Retrieved July 10, 2015, from http://hdr.undp.org/sites/default/files/Country-Profiles/IRN.pdf

Jo, S. H. (2013). The Track of Policies for Educational Equality and Its Implications in Korea. Journal of Educational Change, 14(1), 73-94. https://dx.doi.org/10.1007/s10833-012-9190-5 
Kaviani, K. (2006). Theocratic Education: Understanding the Islamic Republic of Iran by Analyzing its Textbook. Social Studies Research Practice, 1(3), 374-393.

Kim, J. W. (2004). Education Reform Policies and Classroom Teaching in South Korea. International Studies in Sociology of Education, 14(2), 125-146. https://dx.doi.org/10.1080/09620210400200122

Kim, J., \& Chang, J. (2010). Do Governmental Regulations for Cram Schools Decrease the Number of Hours Students Spend on Private Tutoring. KEDI Journal of Educational Policy, 7(1), 3-21.

Kim, S., \& Lee, J. (2010). Private Tutoring and Demand for Education in South Korea. Economic Development and Cultural Change, 259-296. https://dx.doi.org/10.1086/648186

Korea Human Development Report. (2013). Korea (Republic of). Retrieved January 12, 2015, from http://hdr.undp.org/sites/default/files/Country-Profiles/KOR.pdf

Lao, R. (2014). Analyzing the Thai State Policy on Private Tutoring: The Prevalence of the Market Discourse. Asia Pacific Journal of Education, 34(4), 476-491. https://dx.doi.org/10.1080/02188791.2014.960799

Lee, C., Lee, H., \& Jang, H. (2010). The History of Policy Responses to Shadow Education in South Korea: Implications for the Next Cycle of Policy Responses. Asia Pacific Education Review, 11, 97-108. https://dx.doi.org/10.1007/s12564-009-9064-6

Lee, J. (2001). Education Policy in the Republic of Korea: Building Block or Stumbling Block. Washington, D.C: The World Bank, the International Bank for Reconstruction and Development.

Manzon, M. (2014). Comparing Places. In M. Bray, B. Adamson, \& M. Mason (Eds.), Comparative Education Research: Approaches and Methods. University of Hong Kong: CERC Studies in Comparative Education \& Springer. https://dx.doi.org/10.1007/978-3-319-05594-7_4

Mehran, G. (1997). Education in Postrevolutionary Persia: 1979-1995. The Encyclopedia Iranica, 8(3), 230-233. Retrieved February 9, 2015, from http://www.iranicaonline.org/articles/education-xxiv-education-in-postrevolutionary-persia-1979-95

Mehran, G. (2010). Khatami, Political Reform and Education. Comparative Education, 39(3), 311-329. https://dx.doi.org/10.1080/0305006032000134391

Memarian, O. (2010). Activists Warn of Rights Crisis Ahead of Ahmadinejad Visit. Inter Press Service, 17. Retrieved July $10, \quad 2015, \quad$ from http://www.ipsnews.net/2010/09/activists-warn-of-rights-crisis-ahead-of-ahmadinejad-visit/

Menashri, D. (2001). Post-revolutionary Politics in Iran: Religion, Society, and Power. Britain: Routledge.

Mesri, K. (2008). Bankruptcy Crisis of Non-Governmental Schools. Retrieved July 23, 2013, from http://www1.jamejamonline.ir/newstext.aspx?newsnum=100949660021

Ministry of Education. (1999). A Review on Two Decades Effort on Education. Tehran: Research Institute of Education.

Ministry of Education. (2014). Rules and Regulations on Non-Governmental Schools and Open Scientific Centres. Tehran: People Participations and Non-Governmental Schools Organization.

Motevalli, G. (2014). Iran's Brain Drain Is the West's Gain. Bloomberg Business, 8. Retrieved February 8, 2015, from http://www.bloomberg.com/bw/articles/2014-05-08/irans-best-engineering-science-grads-take-skills-abroad

Najmabadi, A. (1987). Iran's Turn to Islam: From Modernism to a Moral Order. Middle East Journal, 41(2), 202-217.

Paivandi, S. (2013). Iran: The Islamization of the School. In A. Mah-E-Rukh (Ed.), Education in West Central Asia. London: Bloomsbury Academic Publishing.

Park, S. (2010). Crafting and dismantling the egalitarian social contract: The changing state-society relations in globalizing Korea. The Pacific Review, 23(5), 579-601. https://dx.doi.org/10.1080/09512748.2010.522247

Qarakhani, M. (2014). Social Policy and State Capacity in Iran: Health and Education Policy from 1981-2009. Journal of Sociology \& Social Welfare, 41(3), 71-83.

Rai, M. (2014). Economic Performance of Four States: Mousavi, Rafsanjani, Khatami and Ahmadinejad. Eghtesad Press. Retrieved February 29, 2015, from http://eghtesadpress.ir/fa/news-details/1469/ 
Rasler, K. (1996). Concessions, Repression, and Political Protest in the Iranian Revolution. American Sociological Review, 61(1), 132-152. https://dx.doi.org/10.2307/2096410

Risen, J. (2000). Secrets of History: The CIA in Iran. New York Times.

Seth, M. J. (2005). Korean Education: A Philosophical and Historical Perspective. In Y. Kim-Renaud, R. R. Grinker, \& K. W. Larsen (Eds.), Korean Education. Washington: The George Washington University.

Siddiqi, A. (2005). Khatami and the Search for Reform in Iran. Stanford Journal of International Relations, 6(1). Retrieved June 11, 2015, from http://www.stanford.edu/group/sjir/6.1.04_siddiqi.html

Silova, I. (2009). Education and Post-Socialist Transformations in Central Asia. In I. Silova (Ed.), Private Supplementary Tutoring in Central Asia: New Opportunities and Burdens. Paris: UNESCO International Institute for Educational Planning.

Skocpol, T., \& Amenta, E. (1986). States and Social Policies. Annual Review of Sociology, 12, 131-157. https://dx.doi.org/10.1146/annurev.so.12.080186.001023

Song, H. K. (2003). Politics, Generation, and the Making of New Leadership in South Korea. Development and Society, 32(1), 103-123.

Spicker, P. (2015). Education and Social Policy. Retrieved February 8, 2015, from http://www2.rgu.ac.uk/publicpolicy/introduction/education.htm

Statistical Center of Iran. (2012). Report on Iran's Population. Retrieved June 10, 2015, from http://www.amar.sci.org.ir

Stevenson, D. L., \& Baker, D. P. (1992). Shadow education and allocation in formal schooling: Transition to university in Japan. American Journal of Sociology, 97(6), 1639-1657. https://dx.doi.org/10.1086/229942

UNdata Iran. (2015). Iran (Islamic Republic). Retrieved March 22, 2015, from https://data.un.org/CountryProfile.aspx?crName=Iran\%20\%28Islamic\%20Republic\%20of\%29

UNdata Korea. (2015). Korea (Republic of). Retrieved April 1, 2015, from https://data.un.org/CountryProfile.aspx?crName=Republic\%20of\%20Korea

UNDP Report. (2013). About Iran. Retrieved February 8, 2015, from http://www.ir.undp.org/content/iran/en/home/countryinfo/

Walsh, M., Stephens, P., \& Moore, S. (2000). Social Policy and Welfare. UK: Cheltenham, Stanley Thornes Ltd.

Wolfgang, L., Cuaresma, J. C., \& Abbasi-Shavazi, M. J. (2010). Demography, Education, and Democracy: Global Trends and the Case of Iran. Population and Development Review, 36(2), 253-281. https://dx.doi.org/10.1111/j.1728-4457.2010.00329.x

Yar Mohammadian, A., Sohrabi, N., \& Arizi, H. (2003). A Comparison of the Konkur's Influence on Universities, Accepted and Rejected Students and Their Families. Psychological Studies, 1(2), 119-136.

\section{Copyrights}

Copyright for this article is retained by the author(s), with first publication rights granted to the journal.

This is an open-access article distributed under the terms and conditions of the Creative Commons Attribution license (http://creativecommons.org/licenses/by/4.0/). 